\title{
PENGARUH MODEL PEMBELAJARAN READING CONCEPT MAP RECIPROCAL TEACHING (REMAP RT) TERHADAP PEMAHAMAN KONSEP MATEMATIKA SISWA KELAS VIII SMP NEGERI 1 SINGARAJA
}

\author{
N. Sumiartini. I. M. Ardana, I. P. W. Ariawan \\ Jurusan Pendidikan Matematika, Universitas Pendidikan Ganesha \\ Singaraja, Indonesia \\ e-mail: nymsumiartini@gmail.com, ardanaimade@undiksha.ac.id,putu wisna ariawan@yahoo.com
}

\begin{abstract}
Abstrak
Penelitian ini bertujuan untuk mengetahui pengaruh model pembelajaran Remap RT terhadap pemahaman konsep matematika siswa. Populasi penelitian ini adalah seluruh siswa kelas VIII non unggulan SMP Negeri 1 Singaraja tahun ajaran 2016/2017. Pengambilan sampel dilakukan dengan teknik cluster random sampling. Sampel pada penelitian ini adalah siswa kelas VIII A6 sebagai kelas kontrol dan VIIIA8 sebagai kelas eksperimen. Desain penelitian yang digunakan dalam penelitian ini adalah post test only control group. Data pemahaman konsep matematika siswa dikumpulkan menggunakan tes pemahaman konsep matematika. Data dianalisis dengan menggunakan uji-t ekor kanan dengan taraf signifikansi $5 \%$. Hasil penelitian menunjukkan bahwa $t_{\text {hitung }}=$ 4,9117. Adapun nilai $t_{\text {tabel }}$ dengan pada taraf signifikasi 0,05 adalah 1,6736 , sehingga $H_{0}$ ditolak. Sehingga pemahaman konsep matematika siswa yang mengikuti pembelajaran dengan model pembelajaran Remap RT lebih baik daripada pemahaman konsep matematika siswa yang mengikuti pembelajaran konvensional. Dengan demikian, penerapan pembelajaran dengan model pembelajaran Remap RT memberikan pengaruh positif terhadap pemahaman konsep matematika siswa.
\end{abstract}

Kata kunci: pemahaman konsep, Remap RT, pembelajaran konvensional.

\begin{abstract}
This objective of this research is to investigate the effect of Remap RT learning model to students' mathematics conceptual understanding. The population were students eighth unseeded grade students of SMP Negeri 1 Singaraja in the academic year of 2016/2017. Sampling was done by cluster random sampling technique. The samples were students in eighth A6 grade students as the control group and eight A8 grade students as the experimental group. The research design used in this research is Post Test Only Control Group Design. Data of students' mathematics conceptual understanding were collected by using students' mathematics conceptual understanding test. This data were analyzed by using a one-tailed $t$-test with $5 \%$ level of significant. This research result show that $t_{\text {calculate }}=4,9117$ greater than $t_{\text {table }}=1,6736$, so that $H_{0}$ is diclined. So that students' mathematics conceptual understanding who studied using Remap RT learning model was higher than those who studied using conventional learning. Thus Remap RT learning model gives positive contribution toward the students' mathematics conceptual understanding.
\end{abstract}

Keywords: conceptual understanding, Remap RT, conventional learning

\section{PENDAHULUAN}

Matematika merupakan ilmu dasar yang memiliki peranan penting dalam proses kehidupan. Hal serupa juga disampaikan oleh Cockcroft dalam Fajar Shadiq (2007: 3) yang menulis "It would be very difficult - perhaps impossible - to live a normal life in very many parts of the world 
in the twentieth century without making use of mathematics of some kind." Sejalan dengan pendapat tersebut, BSNP (2006) menyatakan bahwa untuk menguasai dan menciptakan teknologi di masa depan diperlukan penguasaan matematika yang kuat sejak dini. Berdasarkan pendapat tersebut, matematika merupakan mata pelajaran yang penting untuk dipahami dan dikembangkan.

Dalam Permendiknas RI No 22 Tahun 2006 disebutkan bahwa salah satu tujuan pembelajaran matematika pada pendidikan menengah adalah agar siswa memahami konsep matematika, menjelaskan keterkaitan antar konsep dan mengaplikasikan konsep atau algoritma, secara luwes, akurat, efisien, dan tepat dalam pemecahan masalah. Pemahaman konsep matematika merupakan landasan penting untuk berpikir dalam menyelesaikan permasalahan matematika maupun permasalahan seharihari (Hadi, 2015). Dengan pemahaman konsep matematika yang baik, siswa akan mudah mengingat, menggunakan, dan menyusun kembali suatu konsep yang telah dipelajari serta dapat menyelesaikan berbagai variasi soal matematika. Sejalan dengan pendapat tersebut, Dahar (2011:62) menyebutkan, "Jika diibaratkan, konsep merupakan batu pembangunan dalam berpikir". Akan sangat sulit bagi siswa untuk menuju ke proses pembelajaran yang lebih tinggi jika belum memahami konsep. Oleh sebab itu perlu ditekankan pemahaman konsep matematika siswa. NCTM Principles and Standards for School Mathematics (2000) menyatakan, "students must learn mathe-matics with understanding, actively building new knowledge from experience and prior knowledge." Artinya, siswa harus belajar matematika dengan pemahaman, secara aktif membangun pengetahuan baru dari pengalaman dan pengetahuan sebelumnya.

Namun, mengajarkan konsep matematika tidaklah mudah. $\mathrm{Hal}$ ini dikarenakan masih banyak siswa yang menganggap bahwa pelajaran matematika adalah pelajaran yang sangat menakutkan dan sulit untuk dipahami. Selain itu, banyak siswa yang beranggapan bahwa matematika adalah pelajaran menghafal rumus-rumus sehingga mereka menyimpulkan bahwa matematika tidak menarik dan sangat membosankan. Padahal matematika sebenarnya bukan pelajaran menghafal rumus-rumus, melainkan pelajaran yang memerlukan pemahaman konsep dari setiap materi yang dibelajarkan. Karena mereka tidak tertarik dengan matematika, apalagi ditambah dengan cara pembelajaran yang membosankan seperti ceramah dan hanya berpusat pada guru, secara otomatis siswa juga akan membenci guru matematika yang akan menambah ketidaktertarikan siswa terhadap matematika. Hal seperti ini yang memicu rendahnya pemahaman konsep matematika siswa.

Berdasarkan hal tersebut perlu adanya perencanaan yang baik sebelum melaksanakan pembelajaran. Salah satu perencanaan yang dapat dilakukan adalah dengan memilih suatu model yang dinilai efektif untuk digunakan. Menurut Rusman (2012:133) "model pembelajaran dapat dijadikan pola pilihan, artinya para guru boleh memilih model pembelajaran yang sesuai dan efisien untuk mencapai tujuan pendidikannya". Model pembelajaran yang mampu menciptakan keaktifan siswa di kelas dan memiliki tahapan merangkum materi berupa peta konsep dalam proses pembelajarannya yang secara tidak langsung menyebabkan siswa harus membaca setiap materi pelajaran yang diberikan sebelum pembelajaran dimulai adalah Model Pembelajaran Reading Concept Mapping Reciprocal Teaching yang selanjutnya disingkat dengan Remap RT.

Model Pembelajaran Remap RT adalah integrasi antara model pembelajaran Reading Concept Map Cooperative learning (Remap Coople) dan pembelajaran kooperatif Reciprocal Teaching (RT). Remap Coople merupakan model pembelajaran yang mengharuskan siswa membaca (proses reading) sebelum pembelajaran dimulai, kemudian siswa diminta membuat peta konsep (concept mapping), dan pembelajarannya menggunakan model-model cooperatif learning (Zubaidah, 2014). Sedangkan pembelajaran kooperatif RT menurut Palincsar dan Brown (dalam Sholihah, 2016) menekankan pada aktivitas 
meringkas, membuat prediksi jawaban, dan mengklarifikasi yang dilakukan siswa saat pembelajaran di kelas. Pada model pembelajaran Remap RT, aktivitas meringkas dalam sintaks pembelajaran kooperatif RT terintegrasi dengan aktivitas membuat peta konsep pada sintaks Remap Coople sehingga kegiatan ini dianjurkan agar siswa melaksanakan kegiatan ini di rumah sebelum pembelajaran di kelas berlangsung.

Model Remap RT merupakan salah satu model pembelajaran yang dilaksanakan agar tujuan pembelajaran tercapai melalui kegiatan belajar mandiri dan siswa mampu menjelaskan temuannya kepada pihak lain. Karakteristik dari model pembelajaran ini adalah dialog antara siswa dengan guru dimana masing-masing mendapatkan giliran untuk memimpin diskusi. Adapun sintaks dari model pembelajaran Remap RT yaitu membaca bahan ajar (Reading), membuat peta konsep (Concept Mapping), menyusun dan mengajukan pertanyaan (Questioning), mengklarifikasi pengetahuan yang diperoleh (Clarifying), dan memprediksi pengembangan materi (predicting).

Sintaks pertama adalah tahap membaca (reading) yaitu kegiatan melihat serta memahami isi dari apa yang tertulis. Membaca merupakan suatu proses penangkapan dan pemahaman ide yang dibarengi dengan curahan jiwa dalam menghayati masalah, maka nalar dan intuisi kita bekerja sama dalam memahami dan menghayati bacaan (Amir dan Rukayah, 1996: 3). Membaca juga penting dalam pembelajaran matematika karena Matematika tidak hanya sebatas tentang ilmu pengetahuan eksak, bilangan dan fakta-fakta kuanitatif akan tetapi matematika juga didefinisikan sebagai suatu bahasa, hal tersebut dikemukakan oleh De lang, (dalam Fajar Shadiq 2007: 6) yang menjelaskan bahwa:

Mathematics could be seen as the language that describes patterns - both patterns in nature and patterns invented by thehuman mind. Those patterns can either be real or imagined, visual or mental, static or dynamic, qualitative or quantitative, purely utilitarian or of little more than recreational interest. They can arise from the world around us, from depth of space and time, or from the inner workings of the human mind.

Menurut Anderson (dalam Sugiarti, 2012) dengan membaca siswa akan dapat mengelompokkan atau mengklasifikasikan (reading for classify) mengenai suatu hal sehingga dengan kegiatan ini siswa bisa mengidentifikasi kumpulan obyek, peristiwa atau simbol yang memiliki karakteristik sama. Kumpulan tersebut disebut dengan konsep. Ketika siswa sudah memahami suatu konsep, siswa akan mudah menentukan contoh dan non contoh dari konsep tersebut.

Sintaks kedua adalah tahap Concept Mapping yaitu kegiatan membuat peta konsep. Siswa harus menyusun sendiri peta pikirannya sehingga untuk mendifinisikan suatu konsep harus merangkainya dengan kata-kata sendiri. Karena harus menyusun sendiri peta pikirannya, peta konsep yang dibuat siswa bersifat unik dan akan lebih mudah diingat.

Sintaks ketiga adalah tahap Questioning yaitu kegiatan mengajukan pertanyaaan penting kepada teman kelompok atau kepada teman yang yang bertugas menggantikan guru dalam kelompok. Pertanyaan yang dibuat siswa mencirikan seberapa besar penguasaan siswa terhadap materi yang sudah dipelajari secara mandiri. Pada kegiatan ini pula siswa menguji ide-ide mereka dan ide-ide orang lain sehingga membantu pemahaman konsep siswa.

Sintaks keempat adalah tahap Clarifying yaitu kegiatan dimana salah satu perwakilan kelompok diberi kesempatan untuk mempresentasikan hasil rangkuman dan hasil diskusi mereka dalam kelompok. Dalam hal ini siswa ataupun guru dapat mengklarifikasi kekeliruan pemahaman yang mungkin terjadi terkait dengan materi yang sedang dibahas.

Sintaks terakhir adalah Predicting yaitu kegiatan dimana para siswa belajar untuk memprediksi atau menduga mengenai kemungkinan pengembangan materi yang akan dipelajari selanjutnya. Setelah kegiatan presentasi dan pembahasan materi selesai, siswa dapat mengerjakan soal-soal latihan. baik itu 
dalam hal menyelesaikan permasalahan nyata atau mengaplikasikan materi yang telah dipelajari.

Keunggulan Remap RT yang dipaparkan di atas didukung oleh penelitian Mar'atus Sholihah, Siti Zubaidah, dan Susriyati Mahanal yang menunjukkan model pembelajaran Remap RT dapat meningkatkan keterampilan berpikir kritis siswa lebih tinggi dibandingkan dengan pembelajaran konvensional berbasis pendekatan saintifik. Kemampuan berpikir kritis didasari oleh pemahaman konsep. Pemahaman konsep yang baik sangat diperlukan untuk meningkatkan kemampuan berpikir kreatif, karena pada kemampuan berpikir kreatif siswa dituntut lebih kreatif dalam menerapkan konsepkonsep dan penalaran dalam penyelesaian soal yang secara tidak langsung menuntut siswa untuk memahami konsep terlebih dahulu. Dengan meningkatnya kemampuan berpikir kreatif, maka dipastikan pemahaman konsep juga telah meningkat. Sehingga dapat dilihat keterkaitan antara kemampuan berpikir kreatif dengan pemahaman konsep. Selain itu, penelitian Dwi Rachmayani menunjukkan peningkatan kemampuan komunikasi matematis siswa yang memperoleh pembelajaran reciprocal teaching lebih baik daripada siswa yang memperoleh pembelajaran langsung. Komunikasi Matematis adalah kemampuan siswa untuk menyatakan ide-ide matematika baik secara lisan maupun tertulis. Melalui komunikasi siswa memiliki kemampuan untuk mengaplikasikan dan mengekspresikan pemahaman tentang konsep dan proses matematika yang mereka pelajari. Dengan meningkatnya kemampuan komunikasi matematis, maka pemahaman tentang konsep juga akan meningkat.

Dari hasil penelitian yang telah dsebutkan, diduga model Pembelajaran Remap RT berpengaruh positif terhadap pemahaman konsep matematika siswa. Namun penerapan Remap RT masih mengalami hambatan karena minat baca masyarakat Indonesia sangat rendah. Berdasarkan studi "Most Littered Nation In the World" yang dilakukan oleh Central Connecticut State Univesity pada Maret 2016 lalu, Indonesia dinyatakan menduduki peringkat ke-60 dari 61 negara soal minat membaca (Kompas, 2016).

Berdasarkan deskripsi yang telah dikemukakan di atas, Model Pembelajaran Remap RT (Reading Concept Map Reciprocal Teaching) diduga berpengaruh positif terhadap pemahaman konsep matematika siswa. Untuk mengetahui pengaruh penerapan Model Pembelajaran Remap RT terhadap pemahaman konsep matematika siswa, maka penulis tertarik untuk melakukan suatu penelitian dengan judul "Pengaruh Model Pembelajaran Reading Concept Map Reciprocal Teaching (Remap RT) Terhadap Pemahaman Konsep Matematika Siswa Kelas VIII SMP Negeri 1 Singaraja".

Berdasarkan latar belakang masalah yang telah diuraikan, dapat diperoleh sebuah rumusan masalah sebagai berikut. "Apakah pemahaman konsep matematika siswa yang mengikuti pembelajaran Remap RT lebih baik daripada pemahaman konsep matematika siswa yang mengikuti pembelajaran konvensional?".

Tujuan yang ingin dicapai dari penelitian ini adalah untuk menunjukkan bahwa pemahaman konsep matematika siswa yang mengikuti pembelajaran Remap RT lebih baik daripada pemahaman konsep matematika siswa yang mengikuti pembelajaran konvensional.

\section{METODE}

Penelitian ini merupakan penelitian eksperimen semu (quasi experimen). Penelitian eksperimen semu dapat digunakan untuk melihat pengaruh yang ditimbulkan dari perlakuan berbeda yang diberikan pada masing-masing kelompok, dimana peneliti tidak dapat mengontrol semua variabel dan kondisi eksperimen secara ketat (Sugiyono, 2013:114). Penelitian ini bertujuan untuk menguji pengaruh Model Pembelajaran Remap RT terhadap pemahaman konsep matematika siswa kelas VIII Non Unggulan SMP Negeri 1 Singaraja.

Populasi dalam penelitian ini adalah siswa Kelas VIII Non Unggulan SMP Negeri 1 Singaraja tahun ajaran 2016/2017. Jumlah siswa non unggulan adalah 198 orang siswa yang tersebar ke dalam 7 
kelas, yaitu kelas VIII A2, VIII A3, VIII A4, VIII A5, VIII A6, VIII A7, dan VIII A8.

Penentuan sampel dalam penelitian ini dilakukan dengan teknik cluster random sampling yaitu sampel diambil dari kelompok-kelompok kelas secara acak karena tidak memungkinkan melakukan pengacakan individu sehingga menggunakan kelas yang sudah ada.

Sebelum dilakukan penentuan sampel, terlebih dahulu dilakukan penyetaraan terhadap populasi untuk mengetahui ada tidaknya perbedaan ratarata skor kemampuan awal matematika siswa dengan menggunakan uji ANAVA satu jalur. Data yang digunakan dalam pengujian kesetaraan kelas dalam populasi adalah nilai ulangan umum matematika siswa semester ganjil tahun ajaran 2016/2017.

Sebelum diuji kesetaraannya menggunakan uji ANAVA satu jalur, terlebih dahulu diuji normalitas sebaran datanya dan homogenitas variansnya. Uji normalitas sebaran data populasi menggunakan $\mathrm{Uji}$ Lilliefors. Setelah dianalisis, dapat disimpulkan bahwa data nilai ulangan umum matematika siswa dari ketujuh kelas tersebut dalam populasi berdistribusi normal. Kemudian setelah uji normalitas, dilanjutkan dengan uji homogenitas menggunakan uji Levene. Hasil yang diperoleh adalah data nilai ulangan umum matematika siswa di ketujuh kelas dalam populasi memiliki varians yang homogen.

Selanjutnya dilakukan perhitungan untuk menguji kesetaraan populasi menggunakan uji ANAVA satu jalur (Uji F) Hasil uji kesetaraan dengan menggunakan uji ANAVA satu jalur yang diperoleh $F_{\text {hitung }}=$ 1,288 Adapun nilai $F_{\text {tabel }}$ dengan $\mathrm{dk}$ pembilang $=7-1=6$ dan $\mathrm{dk}$ penyebut $=$ $198-7=191$, pada taraf signifikasi 0,05 adalah 2,1463. Apabila dibandingkan, nilai $F_{\text {hitung }}$ lebih kecil dari nilai $F_{\text {tabel }}$ atau $F_{\text {hitung }}<$ $F_{\text {tabel. }}$ Maka ketujuh kelas dalam populasi tersebut setara. Dari kelas-kelas yang setara tersebut akan dilakukan pengambilan secara acak dengan sistem pengundian. Cara pengambilan kelas sampel dengan sistem undian adalah dua kelas yang muncul dalam undian menjadi sampel penelitian. Selanjutnya, dua kelas muncul yang diundi kembali untuk menentukan kelompok eksperimen dan kelompok kontrol dimana terpilih kelas VIII A8 sebagai kelas eksperimen dan VIII A6 sebagai kelas kontrol

Penelitian ini melibatkan variabel bebas (independent variable) dan variabel terikat (dependent variable). Adapun variabel bebas dalam penelitian ini adalah model pembelajaran dimana model pembelajaran Remap RT diterapkan pada kelas eksperimen dan model pembelajaran kooperatif dan pendekatan scientifik pada kelas kontrol sedangkan variabel terikatnya adalah pemahaman konsep matematika siswa.

Rancangan yang digunakan dalam penelitian ini adalah "Post Test Only Control Group Design" . Terdapat dua kelompok yang menjadi sampel penelitian yaitu kelompok eksperimen dan kelompok kontrol.

Instrumen yang digunakan dalam penelitian ini berupa tes. Data yang akan dikumpulkan pada penelitian ini berupa pemahaman konsep matematika siswa, yang dikumpulkan melalui tes pemahaman konsep matematika. Tes pemahaman konsep matematika yang akan digunakan adalah tes essay. Digunakannya tes essay ini dengan alasan dapat diketahui bagaimana siswa menyatakan konsep dengan kata-kata sendiri, mengidentifikasi contoh dan bukan contoh dari suatu konsep, dan menuangkan pemikirannya secara tertulis terhadap jawaban dari permasalahan yang diberikan.

Untuk memudahkan dalam pemeriksaan dan meminimalisir subjektivitas, dibuat rubrik penskoran untuk tes pemahaman konsep matematika siswa. Pada penelitian ini rubrik yang digunakan adalah dari NCTM pada tahun 2000.

Setelah instrumen tersusun, maka dilakukan uji coba instrumen yang selanjutnya dianalisis dengan uji validitas dan uji reliabilitas. Sebelum di uji cobakan, peneliti menguji instrumen pada judgment untuk mengetahui validitas isi instrumen.

Untuk menguji validitas butir soal essay digunakan koefisien korelasi productmoment dari Carl Pearson (Candiasa, 2010a:38). 
Ujicoba validitas isi tes ini dilakukan dengan meminta bantuan dua orang dosen di lingkungan Jurusan Pendidikan Matematika yang ahli dalam bidang assesment. Uji coba penelitian ini dilakukan di kelas VIII B1 dan VIII B4 SMP Negeri 4 Singaraja. Dimana jumlah soal yang diujicobakan adalah dua belas butir soal. Dari hasil uji coba validitas tes diperoleh dua belas buah soal yang valid. Dua belas soal tersebut diuji reliabilitasnya. Melalui perhitungan diperoleh bahwa $r_{11}=0,638$ dimana dari kriteria yang telah ditetapkan maka derajat reliabilitas tes tergolong tinggi.

$$
t_{h i t}=\frac{\bar{Y}_{1}-\bar{Y}_{2}}{\sqrt{\frac{s^{2}}{n_{1}}+\frac{s^{2}}{n_{2}}}}
$$

dengan:

$$
\begin{aligned}
& s^{2}=\frac{\left(n_{1}-1\right) s_{1}^{2}+\left(n_{2}-1\right) s_{2}^{2}}{\left(n_{1}+n_{2}-2\right)} \\
& s_{1}^{2}=\frac{\sum\left(X_{i}-\bar{X}_{1}\right)^{2}}{n_{1}-1} \quad ; \quad s_{2}^{2}=\frac{\sum\left(X_{i}-\bar{X}_{2}\right)^{2}}{n_{2}-1}
\end{aligned}
$$

(Candiasa, 2010:58)

\section{HASIL DAN PEMBAHASAN}

Data mengenai skor pemahaman

Tabel 1. Rangkuman analisis data skor pemahaman konsep matematika siswa

\begin{tabular}{|c|cc|}
\hline \multirow{2}{*}{ Variabel } & \multicolumn{2}{|c|}{ Sampel } \\
\cline { 2 - 3 } & Kelas Eksperimen & Kelas Kontrol \\
\hline Banyak Siswa $(\mathrm{N})$ & 28 & 30 \\
\hline Rata-rata skor $(\mathrm{X})$ & 37,5357 & 27,9000 \\
\hline Standar Deviasi (SD) & 5,9097 & 8,6676 \\
\hline
\end{tabular}

Sebelum dilaksanakan pengujian untuk memperoleh simpulan, data yang diperoleh harus diuji normalitasnya. Uji normalitas untuk skor kemampuan komunikasi matematika siswa digunakan teknik Lilliefors. Pada pengujian normalitas data dengan teknik Lilliefors, dicari selisih frekuensi sebaran data dengan frekuensi kumulatif sampai batas tiap-tiap data.

Uji homogenitas varians untuk kedua kelompok digunakan Uji Levene dengan menggunakan rumus sebagai berkut:

$$
W=\frac{(N-k) \sum_{i=1}^{k} n_{i}\left(\overline{d_{i}}-\bar{d}\right)^{2}}{(k-1) \sum_{i=1}^{k} \sum_{j=1}^{n}\left(d_{i j}-\overline{d_{i}}\right)^{2}}
$$

(Candiasa, 2010:282)

Setelah diuji normalitas dan homogenitas data selanjutnya akan dilakukan uji hipotesis penelitian. Karena terbukti bahwa data berdistribusi normal dan homogen maka untuk menguji hipotesis nol digunakan uji- $t$ dengan taraf signifikansi $5 \%$ yang dirumuskan konsep matematika siswa diperoleh dari post-test yang diberikan kepada kedua kelompok sampel dapat dilihat pada tabel berikut ini.

Berdasarkan tabel tersebut terlihat bahwa rata-rata skor pemahaman konsep matematika siswa pada kelas eksperimen lebih tinggi daripada rata-rata skor pemahaman konsep matematika siswa kelas kontrol.

Untuk mengetahui apakah pemahaman konsep matematika siswa yang mengikuti model pembelajaran Remap RT lebih baik daripada pemahaman konsep matematika yang mengikuti pembelajaran konvensional maka perlu dilakukan pengujian terhadap $\mathrm{H}_{0}$. Sebelum uji hipotesis dilakukan, terlebih dahulu dilakukan pengujian terhadap normalitas dan homogenitas varians skor tes pemahaman konsep matematika siswa.

Hasil uji normalitas data pemahaman konsep matematika siswa pada kelas kontrol diperoleh $L_{\text {hitung }}=0,0814$ (untuk dk $=\mathrm{n}=30$ pada taraf signifikansi $5 \%$ ) diperoleh $L_{\text {tabel }}=0,1590$. Karena $L_{\text {hitung }}<$ $L_{\text {tabel }}$, maka sebaran data pemahaman konsep matematika siswa pada kelas 
kontrol berdistribusi normal. Sedangkan, hasil uji normalitas data pemahaman konsep matematika siswa pada kelas eksperimen diperoleh $L_{\text {hitung }}=0,103$ (untuk $\mathrm{dk}=\mathrm{n}=28$ pada taraf signifikansi $5 \%$ diperoleh $L_{\text {tabel }}=0,1614$. Karena $L_{\text {hitung }}<L_{\text {tabel }}$, maka sebaran data pemahaman konsep matematika siswa pada kelas eksperimen berdistribusi normal. Jadi dapat disimpulkan kedua kelas sampel beridistribusi normal.

$$
\text { Selanjutnya dilakukan uji }
$$

homogenitas menggunakan Uji Levene. Hasil uji homogenitas varians sebaran data skor pemahaman konsep matematika siswa untuk kedua kelompok dapat dilihat pada tabel berikut. pemahaman konsep matematika siswa kelas kontrol. Untuk kelas eksperimen, ratarata skor pemahaman konsep matematika siswa adalah 37,5357 , sedangkan rata-rata skor pemahaman konsep matematika siswa kelas kontrol adalah 27,9000. Selanjutnya, hasil pengujian hipotesis data skor pemahaman konsep matematika siswa terhadap dua kelas yakni kelas eksperimen dan kontrol di mana karena kedua sampel berdistribusi normal dan variansnya homogen, maka diuji dengan uji- $t$ ekor kanan dan diperoleh kesimpulan bahwa pemahaman konsep matematika siswa yang mengikuti pembelajaran dengan model pembelajaran Remap RT lebih baik daripada pemahaman konsep matematika

Tabel 2. Rangkuman hasil uji Homogenitas varians skor pemahaman konsep matematika siswa

\begin{tabular}{|c|c|c|c|}
\hline Kelompok Sampel & $\mathbf{W}$ & $F_{\text {tabel }}$ & Keterangan \\
\hline Eksperimen & 1,318 & 4,013 & Homogen \\
\hline Kontrol & 1,8 & \\
\hline
\end{tabular}

Dari tabel tersebut, dapat dilihat bahwa $W$ lebih kecil darpada $F_{\text {tabel. }}$. Dengan demikian $\mathrm{H}_{0}$ diterima dan hal tersebut berarti data pemahaman konsep matematika siwa pada kelas sampel mempunyai varians yang homogen.

Pengujian normalitas dan homogenitas menunjukkan bahwa data sampel memiliki sebaran data yang normal dan memiliki varians yang homogen sehingga untuk menguji hipotesisnya digunakan uji-t satu ekor. Hasil perhitungan diperoleh nilai $t_{\text {hitung }}$ adalah 4,9117 dan nilai $t_{\text {tabel }}$ adalah 1,6738. Apabila dibandingkan, nilai $t_{\text {hitung }}$ lebih dari nilai $t_{\text {tabel }}$. Dengan demikian $\mathrm{H}_{0}$ ditolak. Hal ini berarti pemahaman konsep matematika siswa yang mengikuti Model Pembelajaran Remap RT lebih baik daripada pemahaman konsep matematika siswa yang mengikuti pembelajaran konvensional.

Hasil analisis terhadap skor pemahaman konsep matematika siswa terhadap dua kelas sampel yakni kelas eksperimen dan kontrol menunjukkan bahwa rata-rata skor pemahaman konsep matematika siswa pada kelas eksperimen lebih tinggi daripada rata-rata skor siswa yang mengikuti pembelajaran konvensional. Hal ini dikarenakan dalam pembelajaran menggunakan model Remap RT memberi kesempatan kepada siswa untuk belajar secara mandiri, kreatif, dan lebih aktif materi yang akan dipelajari dan berdampak pada meningkatnya pemahaman konsep matematika siswa.

Remap RT terdiri dari 5 tahapan yaitu reading, concept mapping, questioning, clarifying, dan predicting. Masing-masing tahapan tersebut akan dapat membantu siswa untuk membangun sendiri pemahamannya terhadap apa yang sedang mereka pelajari. Pada tahapan reading dan concept mapping siswa dilatih untuk dapat belajar secara mandiri terlebih dahulu dengan membaca materi secara mandiri serta merangkum yang sudah dibaca materi berupa peta konsep. Dengan adanya proses merangkum ini secara langsung siswa terlebih dahulu harus membaca materi pelajaran agar dapat memahami materi yang dipelajari serta mampu untuk dapat menyelesaikan permasalahanpermasalahan dengan berbagai penyelesaian alternatif. Hal ini sejalan dengan pendapat Rahim (dalam Irin, 
2005:5) bahwa proses belajar efektif adalah dilakukan melalui membaca. Selain itu, dalam proses pembelajarannya siswa yang dapat merangkum materi dengan baik dan cepat memperoleh kesempatan untuk menggantikan peran guru yaitu menjadi pemimpin dalam diskusi kelompok. Inilah ciri khas dari pembelajaran dengan Remap $\mathrm{RT}$, yaitu siswa dilatih mandiri dalam belajar yang diperlihatkan pada tahap merangkum dan memberikan kesempatan kepada siswa untuk melatih diri menjadi mentor atau penyalur pengetahuan bagi temantemannya yang kurang dalam memahami pelajaran. Dengan demikian proses belajar menjadi menyenangkan dan siswa lebih mudah memahami konsep.

Pada tahapan Questioning di model pembelajaran Remap RT, siswa mengajukan pertanyaaan penting kepada teman kelompok atau kepada teman yang bertugas menggantikan guru dalam kelompok. Dari tahap bertanya siswa dapat lebih kritis dalam memahami hal baru. Pertanyaan yang dibuat siswa mencirikan seberapa besar penguasaan siswa terhadap materi yang sudah dipelajari secara mandiri. Pada kegiatan ini pula siswa menguji ide-ide mereka dan ide-ide orang lain sehingga membantu pemahaman konsep siswa. Hal ini sejalan dengan penelitian Mar'atus Sholihan, Siti Zubaidah, dan Susriyanti Mahanal pada tahun 2016 yang menujukkan adanya perbedaan keterampilan berpikir kritis antara siswa yang dibelajarkan dengan Model Pembelajaran Remap RT dan pembelajaran konvensional berbasis pendekatan saintifik. Model pembelajaran Remap RT dapat meningkatkan keterampilan berpikir kritis siswa lebih tinggi dibandingkan dengan pembelajaran konvensional berbasis pendekatan saintifik. Kemampuan berpikir kritis didasari oleh pemahaman konsep. Pemahaman konsep yang baik sangat diperlukan untuk meningkatkan kemampuan berpikir kreatif, karena pada kemampuan berpikir kreatif siswa dituntut lebih kreatif dalam menerapkan konsep-konsep dan penalaran dalam penyelesaian soal yang secara tidak langsung menuntut siswa untuk memahami konsep terlebih dahulu. Dengan meningkatnya kemampuan berpikir kreatif, maka dipastikan pemahaman konsep juga telah meningkat. Sehingga dapat dilihat keterkaitan antara kemampuan berpikir kreatif dengan pemahaman konsep.

Pada tahapan Clarifying,salah satu perwakilan kelompok diberi kesempatan untuk mempresentasikan hasil rangkuman dan hasil diskusi mereka dalam kelompok. Dalam hal ini siswa ataupun guru dapat mengklarifikasi kekeliruan pemahaman yang mungkin terjadi terkait dengan materi yang sedang dibahas. Pada tahap klarifikasi ini pula siswa dapat menganalisis dan memilah-milah apa yang sebelumnya sudah mereka pahami tersebut sudah benar atau masih terdapat kesalahan.

Tahapan yang terakhir adalah Predicting yaitu kegiatan dimana para siswa belajar untuk memprediksi atau menduga mengenai kemungkinan penerapan materi yang dipelajari dalam kehidupan seharihari. Setelah kegiatan presentasi dan pembahasan materi selesai, siswa dapat mengerjakan soal-soal latihan. baik itu dalam hal menyelesaikan permasalahan nyata atau mengaplikasikan materi yang telah dipelajari. Tahapan ini menyebabkan meningkatnya pemahaman konsep matematika ditinjau dari indikator pemahaman konsep (NCTM, 2000) yang ketiga yaitu siswa dapat menggunakan konsep dengan benar dalam berbagai situasi.

Ditinjau dari hasil analisis terhadap hasil tes pemahaman konsep matematika siswa menunjukkan bahwa siswa yang mengikuti pembelajaran dengan model pembelajaran Remap RT lebih baik dalam menyatakan kembali konsep dengan katakata sendiri dibandingkan dengan siswa yang mengikuti pembelajaran dengan pembelajaran konvensional karena dengan menerapkan model pembelajaran Remap RT, siswa terbiasa diskusi dengan teman kelompoknya dengan saling mengajukan pertanyaan mengenai materi yang dipelajari dan didukung pada tahap klarifikasi dimana siswa dapat bertanya dan memberikan pernyataan tentang apa yang mereka pahami kepada kelompok lain. Hal ini sejalan dengan penelitian yang Dwi Rachmayani pada tahun 2014 yang menunjukkan peningkatan kemampuan komunikasi matematis siswa yang 
memperoleh pembelajaran reciprocal teaching dibandingkan dengan siswa yang memperoleh pembelajaran langsung. Komunikasi Matematis adalah kemampuan siswa untuk menyatakan ide-ide matematika baik secara lisan maupun tertulis. Melalui komunikasi siswa memiliki kemampuan untuk mengaplikasikan dan mengekspresikan pemahaman tentang konsep dan proses matematika yang mereka pelajari. Dengan meningkatnya kemampuan komunikasi matematis, maka pemahaman tentang konsep juga akan meningkat.

Secara umum, pelaksanaan pembelajaran dengan model pembelajaran Remap RT dapat berjalan baik dan sesuai rencana. Walaupun demikian, dalam pelaksanaannya di kelas tidak luput dari adanya kendala-kendala. Adapun kendalakendala yang dihadapi adalah sebagai berikut.

1. Memerlukan manajemen waktu yang baik dalam persiapan maupun pelaksanaan proses pembelajaran dengan menggunakan model pembelajaran Remap RT. Hal ini disebabkan adanya kegiatan reading dimana setiap siswa memiliki kecepatan yang berbeda dalam mebaca sehingga harus mengatur waktu dengan baik.

2. Siswa merasa kebingungan saat model ini pertama kali diterapkan sehingga siswa memerlukan waktu untuk terbiasa. Oleh karena itu, diperlukan upaya ekstra diawal pembelajaran agar maksud model pembelajaran dapat dipahami siswa.

3. Pada saat perwakilan kelompok diminta untuk mempresentasikan hasil diskusi di depan kelas, siswa masih terlihat malu-malu untuk menyampaikan kepada siswa lain. Pada awal pertemuan hanya sedikit siswa yang berani mengajukan pertanyaan.

Namun kendala-kendala tersebut dapat ditangani dengan baik. Kendalakendala tersebut dapat ditangani dengan membatasi waktu untuk masing-masing kegiatan agar tidak terjadi kekurangan waktu selama proses pembelajaran.
Kemudian, pada setiap awal pertemuan guru harus mengingatkan kembali tahapantahapan pembelajaran yang harus dilakukan oleh siswa. Yang terakhir adalah dengan memberikan motivasi kepada siswa dengan memberikan petunjuk berupa pernyataan atau pertanyaan yang mebuat siswa terpacu lebih aktif dalah tahap diskusi. Selain itu, dengan mewajibkan setiap kelompok mengajukan pertanyaan pada awal-awal pertemuan akan memberikan tanggung jawab kepada siswa untuk bertanya sehingga siswa akan semakin terpacu untuk memahami materi dan pada akhirnya mendorong siswa lebih aktif mengajukan pertanyaan.

Berdasarkan hasil pengujian hipotesis di atas, dapat dilihat bahwa pembelajaran dengan model pembelajaran Remap RT berpengaruh positif terhadap pemahaman konsep matematika siswa. Hal ini dibuktikan dengan hasil post-test yang menunjukkan bahwa pemahaman konsep matematika siswa yang mengikuti pembelajaran dengan model pembelajaran Remap RT lebih baik daripada siswa yang mengikuti pembelajaran konvensional.

\section{SIMPULAN DAN SARAN}

Berdasarkan uraian pada hasil penelitian dan pembahasan, dapat disimpulkan bahwa pemahaman konsep matematika siswa yang mengikuti pembelajaran dengan model pembelajaran Remap RT lebih baik daripada pemahaman konsep matematika siswa yang mengikuti pembelajaran konvensional. Jadi, pembelajaran matematika dengan model pembelajaran remap RT memberikan pengaruh positif terhadap pemahaman konsep matematika siswa.

Berdasarkan hasil penelitian yang diperoleh, peneliti melalui tulisan ini mengajukan beberapa saran. Adapun saran-saran yang dapat disampaikan adalah sebagai berikut. Bagi praktisi pendidikan, khususnya yang terlibat dalam pembelajaran matematika disarankan untuk mempertimbangkan model pembelajaran Remap RT ini sebagai salah satu alternatif model pembelajaran yang dapat diterapkan di kelas terutama apabila ingin meningkatkan pemahaman konsep matematika siswa. 
Penelitian ini dilakukan pada populasi yang terbatas. Para peneliti lain yang tertarik disarankan untuk melakukan penelitian terhadap model pembelajaran Remap RT ini dengan sampel yang lebih besar untuk mengetahui pengaruh penerapan model pembelajaran Remap RT dalam pembelajaran matematika secara lebih mendalam.

\section{DAFTAR PUSTAKA}

BSNP. 2006. Panduan Penyusunan Kurikulum Tingkat Satuan Pendidikan Jenjang Pendidikan Dasar dan Menengah. Jakarta : BSNP.

Candiasa. 2010. Statistik Univariat dan Bivariat Disertai Aplikasi SPSS. Singaraja: Unit Penerbitan Universitas Pendidikan Ganesha.

Hadi, Sutarto \& Maidatina Umi Kasum. 2015. "Pemahaman Konsep Matematika Siswa SMP melalui Penerapan Model Pembelajaran Kooperatif Tipe Memeriksa Berpasangan (Pair Checks)". Jurnal Jurusan Pendidikan Matematika Universitas Lambung Mangkurat Vol.3, No.1. Tersedia pada:

http://ppip.unlam.ac.id/journal/inde x.php/edumat/article/view/630. Diakses, 2 Februari 2017.

Irin, P. S. 2005. Hubungan Minat Baca dengan Prestasi Belajar Siswa Pada Pembelajaran IPS Geografi. Skripsi (tidak diterbitkan) tersedia pada

http://kim.ung.ac.id/index.php/KIM FMIPA/article/download/3641/3617 Diakses, 22 Mei 2017.

NCTM. 2000. Principle and Standards for School Mathematic. Virginia: NCTM.

Rusman. 2012. Model-model Pembelajaran Mengembangkan Profesionalisme Guru. Jakarta: PT Rajagrafindo Persada, Cet, ke-5.
Shadiq, Fajar. 2007. Apa dan Mengapa Matematika itu Penting. Yogyakarta: Widyaiswara

Sugiarti, Uci. 2012. "Pentingnya Pembinaan Kegiatan Membaca sebagai Implikasi Pembelajaran Bahasa Indonesia". Jurnal Universitas Negeri Medan. Tersedia: http://jurnal.unimed.ac.id/2012/inde x.php/basastra/article/viewFile/201/ 80 Diakses, 22 Januari 2017.

Sugiyono. 2015. Metode Penelitian Pendidikan (Pendekatan Kuantitatif, Kualitatif, dan R\&D). Bandung: Alfabeta.

Zubaidah, Siti. 2014. "Pemberdayaan Keterampilan Penemuan dalam Scientific Approach melalui Pembelajaran Berbasis Remap Coople". Jurnal Jurusan Biologi Universitas Negeri Malang. Tersedia pada:

http://jurnal.fkip.uns.ac.id/index.php/ prosbio/article/view/4990. Diakses, tanggal 17 Januari 2017. 